\title{
ENVIRONMENTAL INDICATORS IN FOREST FRAGMENTS FROM URBAN WATERSHEDS
}

\author{
REGINA MÁRICIA LONGO ${ }^{1}$, ALESSANDRA LEITE DA SILVA ${ }^{1}$, SUELI DO CARMO BETTINE ${ }^{1}$, \\ ANTONIO CARLOS DEMAMBORO ${ }^{1}$, ADRIANO BRESSANE ${ }^{1}$, \\ FELIPE HASHIMOTO FENGLER ${ }^{2} \&$ ADMILSON ÍRIO RIBEIRO ${ }^{2}$ \\ ${ }^{1}$ Urban Infrastructure Systems, Pontifical Catholic University of Campinas, Brazil \\ ${ }^{2}$ São Paulo State University, Brazil
}

\begin{abstract}
Accelerated urbanization in Brazil promoted the rapid growth of cities and, in most cases, was not based on adequate land use planning. The result was the intense fragmentation of the landscape, causing the destruction and fragmentation of forest habitats, which were restricted to small and isolated remnants. In this sense, the present study promoted an analysis of the environmental quality of vegetation fragments in the sub-basins of Ribeirão Anhumas, Campinas, São Paulo, Brazil by calculating and interpreting the circularity index (CI), in order to define the format of the fragments, connectivity/ isolation and the use and occupation of the environment as well as area and location, in order to promote the diagnosis and identification of priority areas for the implementation of restoration and environmental management actions. It was identified, therefore, that the remaining vegetation of the upper, middle and lower sub-basins is divided between small and medium unconnected fragments of which $56.2 \%$ and $24.2 \%$ presented an elongated and moderately elongated shape, respectively, and, therefore, high susceptibility to external interference and edge effects. On the other hand, high urbanization evidenced mainly in the high-level limits forest management projects, since the fragments are surrounded by built areas.
\end{abstract}

Keywords: urbanization, remaining vegetation, environmental indicators.

\section{INTRODUCTION}

Fragmentation refers to the process of transformation of the original forest matrix into isolated areas of remnant vegetation, commonly referred to as forest fragments [1]. Forest fragments are defined as any vegetated areas that present some kind of interruption in their extension, coming from natural elements, such as lakes and rivers, as well as anthropic ones, such as agricultural culture, built-up areas, access roads, etc. [2]. This process changes the environmental conditions of these areas, which, in most cases, present few similarities to the original habitat, given physical and structural changes such as: the greater relation between area and perimeter, greater proximity of the central region to the border areas and reduction of populations of flora and fauna [3].

This scenario is quite common in tropical forests, such as Atlantic Forest and Amazon Rainforest, for various reasons. A study by [4] pointed out that the intense deforestation rate in Amazonia, mainly due to the advent of agribusiness and industrial forestry, has left islands of remaining vegetation amid a sea of deforested habitats, provoking physical and biological effects ranging from the reduction of populations to changes in micro and macroclimate. The Atlantic Forest, on the other hand, is one of the biomes that suffered the most from the economic explorations in Brazil and in which the landscape is very similar: intense forest fragmentation, resulting in few areas of continuous vegetation, subject to several degrees of degradation [5].

For the analysis of the remaining fragments of vegetation it is essential to evaluate the geographic and spatial indicators related to these fragments. Noteworthy in the literature are the number and size of fragments, central area of the same, perimeter/area ratio, edge density, shape of the fragment, spatial distribution, proximity to native vegetation and proximity to 
the hydrographic network [1], [2], [6]-[15]. Indicators of the physical environment such as soil parameters, vegetation and water quality are also important indicators of environmental quality in urban forest environments [16]-[18].

The quantification of the number of fragments present in a particular area of study, as well as the size of these fragments, when associated with other evaluation parameters, work as excellent indicators. This is because, they transmit information about the intensity of fragmentation and contribute efficiently to the identification of the fragility degree of these remaining areas, mainly fragility to edge effects [1], [6]. [9] also highlight the area of the fragments as one of the most important parameters for the understanding of the variations of species richness in the areas of remaining vegetation.

They also stand out as indicators of disturbance: use and occupation at the border, intensity of fragmentation, proximity between fragments and built areas, proximity to urban centers, proximity between fragments and access routes [6], [11], [19], [20]. The identification of the use and occupation of the soil in the regions bordering the fragments is important, since different uses exert different pressures on them; the presence of anthropic activities and lower soil cover, for example, exert greater pressure on the remaining vegetation areas and, consequently, indicate a greater need for recovery. In addition, changes in the pattern of use and occupation may represent disturbances to the environment, promoting ecosystem modifications [6], [19]. The survey of the classes of use and occupation around the fragments makes it possible to identify their proximity to areas of greater pressure, such as built-up areas, urban centers and roads. [6] and [19] suggest that the greater proximity of the fragments to urban areas is one of the criteria that point to the priority of recovery of these areas, since they indicate a greater environmental disturbance. To do so, they considered a radius of $200 \mathrm{~m}$ from the edges of the fragments to identify or not the presence of urban areas in this area. Similarly, there is the proximity between fragments and pathways, that is, road mesh. [11] emphasizes that the proximity of forest fragments of the road network exerts the same negative influence that comes from the urban centers, since there is a great tendency to reduce area, or even extinction.

In this sense, the present study promoted an analysis of the environmental quality of vegetation fragments in the sub-basins of Ribeirão Anhumas, Campinas, São Paulo, Brazil by calculating and interpreting the circularity index $(\mathrm{CI})$, in order to define the format of the fragments, connectivity/isolation and the use and occupation of the environment as well as the area and location, in order to promote the diagnosis and identification of priority areas for the implementation of restoration and environmental management actions.

\section{MATERIAL AND METHOD}

The present work was carried out in the Anhumas River Basin located in the city of Campinas, São Paulo, Brazil, being delimited by UTM coordinates, Zone $23 \mathrm{~S}$, from $7,462,827$ to $7,482,500 \mathrm{~N}$ and from 282,500 to $296,870 \mathrm{~L}$, according to Fig. 1 . It is a watershed almost entirely located in an urban area of the municipality and in the Mata Atlântica biome, with a small portion of Cerrado located in the northernmost part.

According to [21] the predominant area are: Latosols, Argisols, Gleysols, Nitosols, Neosols and Cambisols. However, in the region there is predominance, mainly, of Latosols and Argisols, which represent a percentage of $52.9 \%$ and $39.7 \%$ of the total, respectively. According to Brazil's climatic classification according to [22], the Anhumas River Basin is located entirely in an area characterized by a tropical climate, called Tropical Central Brazil. For the identification of forest remnants, the soil use and occupation data of the Anhumas River Basin provided by [23] and updated by field checks in the year 2017 were used as a basis. 

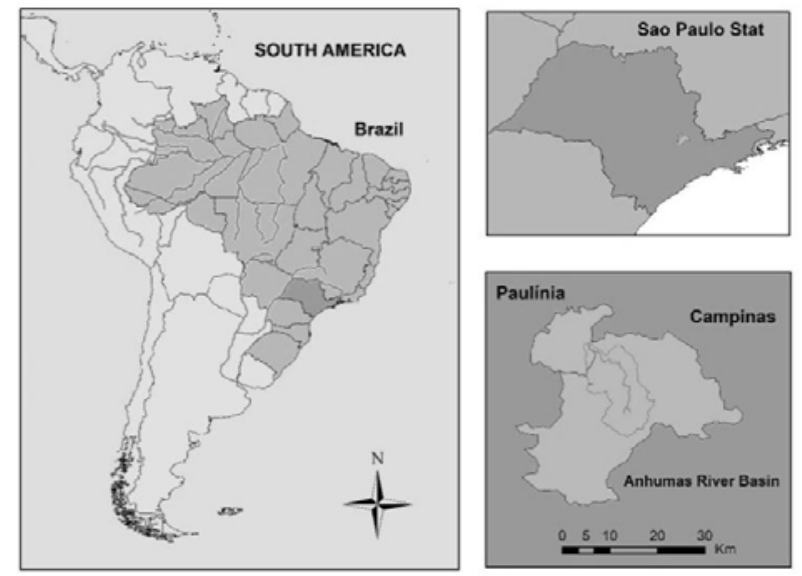

Figure 1: Location of the Anhumas River Basin.

Table 1: Shape of forest fragments according to circularity index (CI). (Source: [24].)

\begin{tabular}{|c|c|}
\hline Circularity index & Form \\
\hline$<0.65$ & Elongated \\
\hline $0.65-0.85$ & Moderately elongated \\
\hline$>0.85$ & Rounded \\
\hline
\end{tabular}

In relation to environmental quality indicators, the circularity index $(\mathrm{CI})$ was used to identify the degree of proximity of the shape of the forest remnant with that of a circumference. It establishes the shape of a circumference as a theoretical standard of comparison to the shape of the fragments, since in this case the edge area is minimized in relation to the total area, thus reducing edge effects. This index is therefore of great importance for the study in question and was calculated by means of the relation between area and perimeter of the forest fragments, according to eqn (1) [2], [6].

$$
C I=\frac{(2 \cdot \sqrt{\pi \cdot A})}{L},
$$

where $C I=$ circularity index, $A=$ fragment area, $L=$ length or fragment.

Thus, the closer to 1 the index was, the more circular was the remainder; on the other hand, distant indexes of 1 represent fragments of more elongated shape, in which the proximity between the central area and the edges is greater, and, finally, their vulnerability is greater [6], [13], [14]. For identification of the shape of the fragments, they were classified according to the circularity index, according to the methodology of [24], as presented in Table 1 and a map was constructed.

Following the method used by [6] were considered as areas around the fragments those that are at a distance of up to $175 \mathrm{~m}$ from the edge. For that, $175 \mathrm{~m}$ buffers were generated for each fragment. With the aid of the land use and land cover [23] and aerial images, these bands around the fragments were evaluated manually and individually and classified according to [20] in 5 groups, according to the intensity of modification of the natural landscape are:

Class 0 Unmodified: covering natural or almost natural landscapes, with very low degree of use and occupation of the soil, such as native cerrado or forest. 
Class 1 Minor modification: natural vegetation with small modification, low degree of use and occupation.

Class 2 Medium modification: transition areas, medium degree of use and land occupation, such as parks and planted pastures.

Class 3 High modification: much modification of the natural landscape and high degree of use and occupation of the soil; characterized by deforested areas, dirt roads, orchards.

Class 4 Modification very high: completely modified areas, with very high use and occupation of the ground, such as: exposed soil, degraded areas, paved streets, buildings, etc.

In order to determine the connectivity of the fragments, the presence or absence of intersections between two or more fragments was evaluated through the generation, in GIS software, of buffers of $175 \mathrm{~m}$ from the edge of the remnants. The intersection between one or more buffers generated around the fragments indicated that the distance between them was a maximum of $350 \mathrm{~m}$. It was considered, therefore, that for such fragments there was connectivity, since [25] the animal trafficability is limited around $350 \mathrm{~m}$ distance. A map was constructed to represent fragments with connectivity potential.

The determination of the environmental quality of the fragments was performed according to a simplified adaptation of the multi-criteria analysis method used by [25] and [26] in the evaluation of forest fragments in the Jundiaí-Mirim River basin, in the interior of São Paulo. This method was based on the principle of value weighting. In which there is possibility to compare the evaluated points in reference to a point considered as ideal. [25] points out that in anthropized environments the ideal quality point is practically unattainable; despite this, it is possible to identify fragments with more urgent needs, leading to appropriate management and management solutions. In the present work, this analysis was performed by weighting the indicators total area (size), circularity index (CI), nuclear area, connectivity and degree of occupation in the around, through grades that ranged from zero (0) to ten (10) according to the criteria presented in Table 2.

The environmental quality Qf was then evaluated by the summation of the score of the indicators mentioned above, indicating how far from the ideal, summation of the maximum values $(\mathrm{Qf}=50)$, the fragments are found.

Table 2: Criterion for assessing indicators in forest fragments.

\begin{tabular}{|c|c|c|c|c|c|c|c|c|c|}
\hline \multicolumn{2}{|c|}{ Área (ha) } & \multicolumn{2}{|l|}{$\begin{array}{l}\text { Circularity } \\
\text { Index (CI) }\end{array}$} & \multicolumn{2}{|c|}{$\begin{array}{c}\text { Nuclear } \\
\text { Area * }(\%)\end{array}$} & \multicolumn{2}{|c|}{ Connectivity } & $\begin{array}{l}\text { Use and } \\
\text { around }\end{array}$ & Occupation \\
\hline$<0,50$ & 0 & $<0,65$ & 3 & $<5 \%$ & 0 & No & 3 & Classe 4 & 1 \\
\hline $0,50-1,00$ & 1 & $0,65-0,85$ & 7 & $05-20$ & 2 & Yes & 10 & Classe 3 & 3 \\
\hline $1,00-5,00$ & 5 & $>0,85$ & 10 & $20-40$ & 4 & & & Classe 2 & 5 \\
\hline $\begin{array}{ll}5,00 & - \\
20,00 & \end{array}$ & 8 & & & $40-60$ & 6 & & & Classe 1 & 8 \\
\hline$>20,00$ & 10 & & & $60-70$ & 8 & & & Classe 0 & 10 \\
\hline & & & & $>70$ & 10 & & & & \\
\hline
\end{tabular}

* Percentage in relation to the total area of the fragment. 


$$
Q f=\sum \text { score of each indicator. }
$$

In order to facilitate comparisons and to enable the environmental quality evaluation in these fragments, Qf values were normalized to values between 0 and 1 according to eqn (3).

$$
Q f_{\text {normal }}=\frac{\left(Q f_{\text {frag. }}-Q f_{\text {mín. }}\right)}{\left(Q f_{\text {máx. }}-Q f_{\text {mín. }}\right)}=\frac{(Q f-0)}{(50-0)}=\frac{Q f}{50} .
$$

Using the methodology used to determine the environmental quality of forest fragments used by [25], the classification of the fragments according to their environmental quality (Qf) was then used in five groups, according to Table 3.

\section{RESULTS AND DISCUSSION}

The shape of a forest fragment can be directly related to its respective circularity index, since the latter makes an association between the shape of the fragment and a circle of the same area. In this way, the fragments of the Anhumas River Basin could be classified as elongated, moderately elongated or rounded. It was identified that more than $50 \%$ of the fragments presented circularity index between 0.65 and 0.85 , classifying them as moderately elongated while very few were classified as rounded (Table 4).

The more rounded a fragment, the more compact it is and the lower its vulnerability to the activities of the surrounding soil use, since the central portion of the fragment tends to remain equidistant from the edge, maintaining a relative protection [6]. Thus, the shape of the forest fragment may influence important local ecological processes, for example, on the migration or escape of animals, plant colonization [7]. However, as already pointed out, the big question is that fragments whose shape is closest to the ideal are those with very small areas (Fig. 2); this is a trend already predicted by [25].

Table 3: Criterion for assessing the environmental quality of forest fragments.

\begin{tabular}{c}
\hline Score Qf \\
\hline $0.00-0.20$ \\
\hline $0.20-0.40$ \\
\hline $0.40-0.60$ \\
\hline $0.60-0.80$ \\
$\frac{\text { Environmental quality }}{\text { Very low }}$ \\
\hline
\end{tabular}$-\frac{\text { Low }}{\text { Mean }}$

\begin{tabular}{|c|c|c|c|c|c|c|}
\hline \multirow[b]{2}{*}{$\begin{array}{l}\text { Circularity } \\
\text { Index (CI) }\end{array}$} & \multicolumn{6}{|c|}{ No of fragments } \\
\hline & $\begin{array}{c}\text { Form of } \\
\text { fragments }\end{array}$ & $\begin{array}{l}\text { Upper } \\
\text { course }\end{array}$ & $\begin{array}{l}\begin{array}{l}\text { Middle } \\
\text { course }\end{array} \\
\end{array}$ & $\begin{array}{c}\text { Low } \\
\text { course }\end{array}$ & Total & $\%$ \\
\hline$<0.65$ & Elongated & 6 & 11 & 31 & 48 & 37.50 \\
\hline $0.65-0.85$ & $\begin{array}{c}\text { Moderately } \\
\text { elongated }\end{array}$ & 12 & 12 & 45 & 69 & 53.91 \\
\hline$>0.85$ & Rounded & 3 & 1 & 7 & 11 & 8.59 \\
\hline \multicolumn{2}{|c|}{ TOTAL } & 21 & 24 & 83 & 128 & 100.00 \\
\hline
\end{tabular}

Table 4: Index of circularity and shape of the forest fragments by sub-basins. 


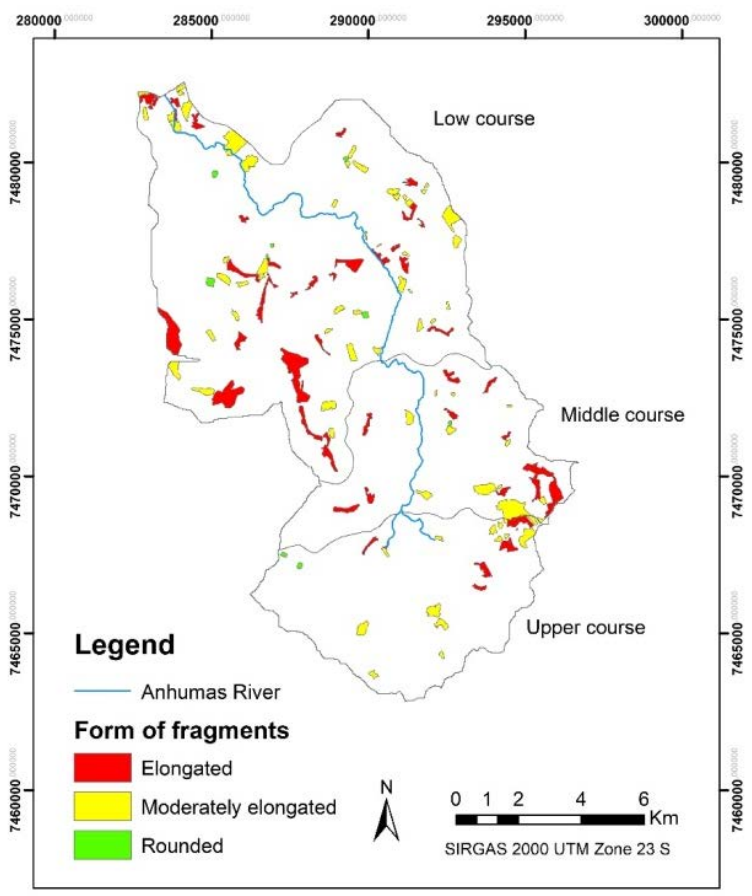

Figure 2: Classification of forest fragments in the to their format.

Some authors [2] were able to identify that only 3 remnants in the Ribeirão das Pedras sub-basin, Campinas, São Paulo, Brazil, had adequate circularity indexes and, therefore, shape close to the ideal; moreover, all these corresponded to a very small area; in contrast, the other 61 fragments had elongated or very elongated shapes. On the other hand, the analysis performed by [27] presented very different results: $66.67 \%$ of the evaluated fragments were identified with rounded formats because they presented circularity indexes higher than 0.72; it is worth noting, however, that in this case they were fragments inserted in a farm of eucalyptus that, therefore, exerted much less external pressures on the remnants than a highly urbanized region.

It is also highlighted that the association between small sizes and irregular shapes is one of the main causes for the decrease of nuclear area in the forest fragments [14]. They are therefore an essential indicator in the evaluation, management and monitoring of forest fragments, especially in urban areas where external pressures are high.

Understanding the degree of use and occupation of the soil around the fragments is essential to evaluate how and with what intensity the external area has influence on forest remnants. This indicator was evaluated by analyzing the degree of landscape modification in these areas bordering the fragments. As it is a predominantly urban region, it was identified that most of the forest fragments present in the Anhumas Basin are surrounded by areas of high and/or very high modification (Fig. 3), classified as such due to characteristics such as: deforested areas and/or degraded, streets, exposed soil, buildings, etc. [20]. The percentage of fragments surrounded by landscapes of very high modification was even more representative in the high-grade sub-basin, where the center of the city of Campinas is located and where the highest population density is found [28]. 

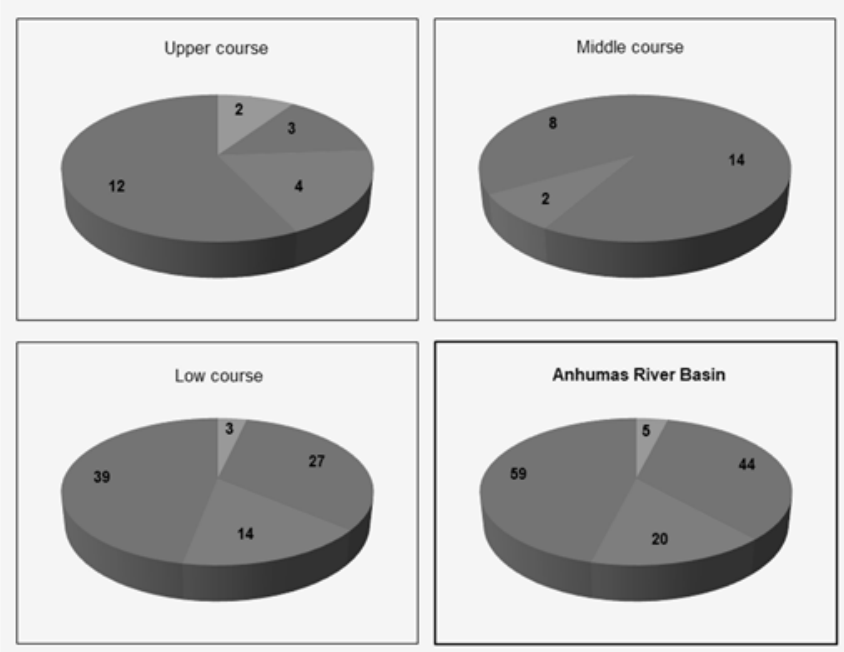

= Class 1: Minor modification

- Class 3: High modification

- Class 2: Medium modification

- Class 4: Modification very high

Figure 3: Number of fragments per class of modification in the use and occupation.

According to [6] the analysis of this indicator is relevant because the changes in the way of use and occupation of the soil at the borders of the fragments can act to promote modifications in the forest ecosystem of the fragment, resulting, in this way, in a disturbed environment. By means of the classification in different degrees of modification of the landscape predicted by [20] and adopted in the present work it was realized that the urbanization is part of one of the stages of major modifications in a landscape once natural. [25] emphasizes that, in addition, urbanization is related to other pressure factors, including the intensity of fragmentation, the remaining vegetation cover and the size of the fragments.

As for other indicators, such as the circularity index, the data presented in Fig. 3 revealed further information. From the analysis of Table 5 and Fig. 4, it was observed that although the river basin presents fragments with circularity indexes considered as "good", these fragments were mostly surrounded by areas of high occupancy (Class 4), suffering, therefore, a great pressure of the external environment. It was found that this acts as an additional aggravating factor of the edge effect, which may considerably affect the self-sustainability capacity of the fragments.

Although they are located in areas with modifications that increase the external pressure and vulnerability of the fragments, the analysis of the connectivity indicator could be evaluated that they are relatively close to each other, which is a beneficial factor. Table 6 shows that $83.6 \%$ of the fragments of the Anhumas River Basin presented connectivity with one or more fragments in a radius of $350 \mathrm{~m}$, while $16.4 \%$ were completely isolated, considering this same range. Connectivity between fragments is an essential factor for the maintenance of gene flow and biodiversity in remaining areas. In contrast, isolated fragments are poorer in biological diversity and are more likely to be populated by invasive plant species [12]. [29] also emphasizes that when the phenomenon of isolation lasts for a long time the fragments tend to degenerate due to the loss of pollinators, dispersers and predators. This causes imbalance in biodiversity and especially affects endemic and low population density species. 
Table 5: Relation between occupation use classes in the surroundings of the fragments and their respective circularity indices.

\begin{tabular}{|c|c|c|c|c|c|}
\hline \multirow[b]{2}{*}{$\begin{array}{l}\text { Circularity index } \\
\text { (CI) }\end{array}$} & \multicolumn{5}{|c|}{ No of fragments } \\
\hline & Class 0 & Class 1 & Class 2 & Class 3 & Class 4 \\
\hline $0.00-0.20$ & - & - & - & - & - \\
\hline $0.20-0.40$ & - & - & - & - & - \\
\hline $0.40-0.60$ & - & 1 & 6 & 4 & 20 \\
\hline $0.60-0.80$ & - & 2 & 27 & 12 & 30 \\
\hline $0.80-1.00$ & - & 2 & 11 & 4 & 9 \\
\hline TOTAL & - & 5 & 44 & 20 & 59 \\
\hline
\end{tabular}

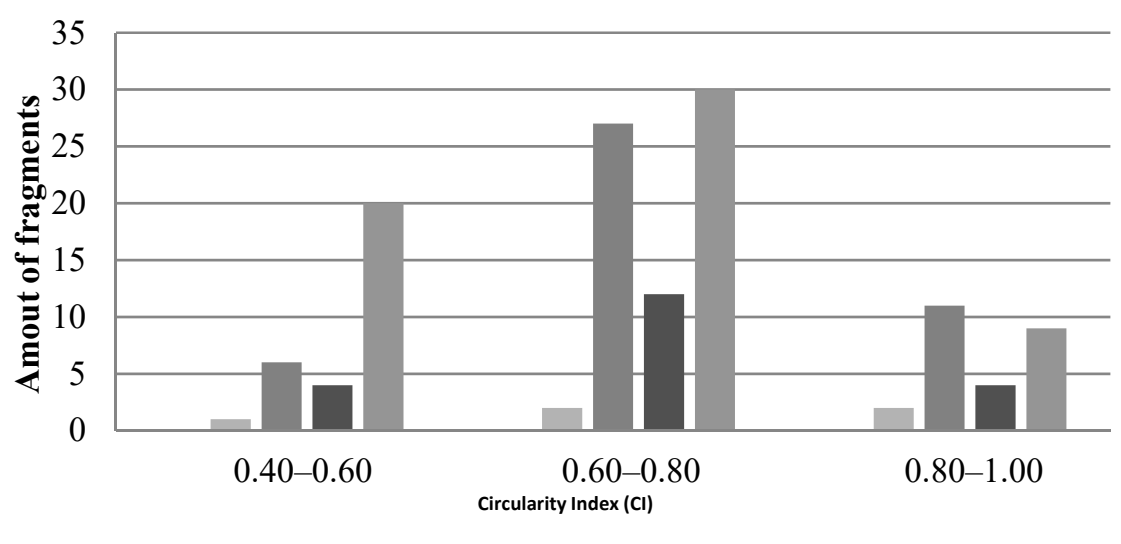

- Class $0 \quad \square$ Class $1 \quad \square$ Class $2 \quad \square$ Class $3 \quad$ Class 4

Figure 4: Degree of modification in the surroundings of the forest fragments in the River Anhumas Basin for each range of circularity index.

Table 6: Connectivity in the forest fragments of the Anhumas River Basin.

\begin{tabular}{|c|c|c|c|c|}
\hline \multirow{2}{*}{ Sub-basin } & \multicolumn{2}{|c|}{ With connectivity } & \multicolumn{2}{|c|}{ No connectivity } \\
\hline & No & $\%$ & No & $\%$ \\
\hline Upper course & 15 & 66.7 & 6 & 28.6 \\
\hline Middle course & 19 & 83.3 & 5 & 20.8 \\
\hline Low course & 73 & 88.0 & 10 & 12.0 \\
\hline Total & 107 & 83.6 & 21 & 16.4 \\
\hline
\end{tabular}

The values presented in Table 6 demonstrated a favorable situation to the connectivity of the fragments in the Anhumas River Basin, mainly in the medium and low sub-basins; most them $(83.3 \%$ and $88.0 \%$, respectively) are close to some more fragment in a maximum distance of $350 \mathrm{~m}$. This situation may favor the management and preservation of these 
remaining forest areas through, for example, the implementation of ecological corridor projects that connect such fragments.

Ecological corridors are not only considered as linear structures (corridors) that connect two fragments (spots) in the landscape, as well as understood in the ecological perspective, but as spatial structures that allow the flow of seeds and the displacement of the fauna within the concept of geographic network, so as not to present barriers or impedances to movement [30].

In addition, the adoption of ecological corridors that aim at the connection between previously isolated fragments are a main alternative currently adopted as a management strategy for the conservation of biodiversity [30]. Although the most suitable fragments for this type of action are those of great value for environmental conservation, generally fragments of larger area, including the smaller fragments is also very important, since they can act as trampolines for migrating species and/or move for close fragments [12]. [11] points out that for biological conservation in a fragmented landscape there must be, in addition to large fragments, a network of smaller fragments that work to increase the functional connectivity between these areas. In addition, according to [1] the union of smaller fragments through ecological corridors established through vegetation recomposition contributes to the increase of nuclear areas in the fragments, increasing their stability. In the case of the Anhumas River Basin: highly urbanized, with fragments that despite being classified as "good" have a very low percentage of nuclear area and in which there was a considerable number of fragments with connectivity potential (Fig. 5(a)), actions since type, ecological corridors, are highly recommended [15].

Regular monitoring of the number of forest fragments in a given area is also indicated for management purposes; because the decrease in the number of fragments in a basin or subbasin may erroneously be interpreted as an increase in the connectivity of the fragments. However, as observed by [6], what often happens is just the opposite, that is, the disappearance of smaller fragments due to deforestation processes or edge effect.

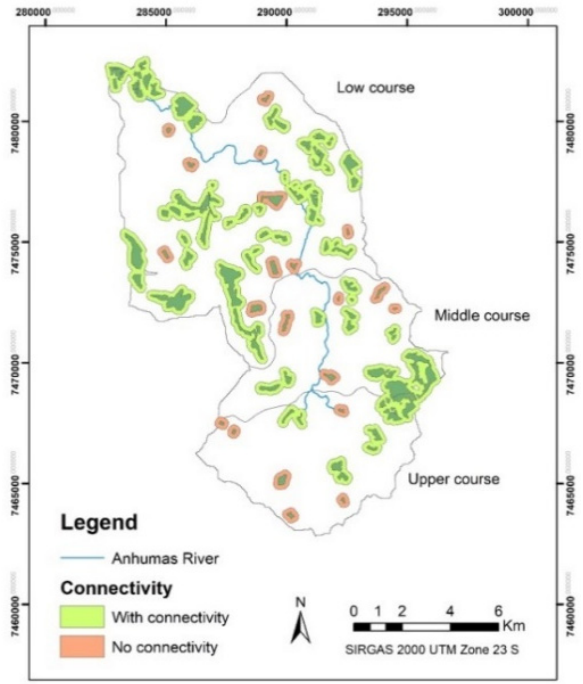

(a)

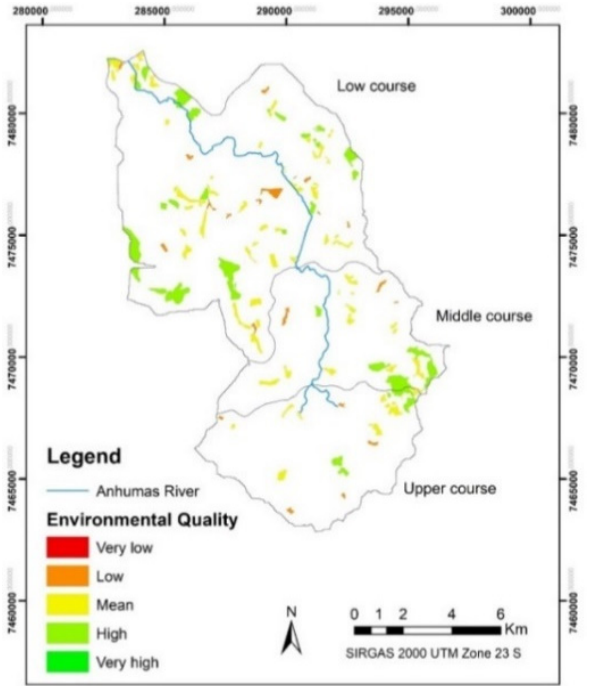

(b)

Figure 5: (a) Connectivity between the forest fragments in the Anhumas River Basin; and (b) Environmental quality of forest fragments - spatial distribution. 
Table 7: Environmental quality of forest fragments.

\begin{tabular}{|c|c|c|c|c|c|c|c|c|c|}
\hline & & & & & & & & & \\
\hline & & & & No o & fragm & its (n & & & \\
\hline$Q f$ normal & Environmental & & & & $\begin{array}{l}\text { Idle } \\
\text { Irse }\end{array}$ & Lon & ourse & & \\
\hline & & $\mathrm{n}$ & $\%$ & $\mathrm{n}$ & $\%$ & $\mathrm{n}$ & $\%$ & $\mathrm{n}$ & $\%$ \\
\hline $0.00-0.20$ & Very low & - & - & - & - & - & - & - & - \\
\hline $0.20-0.40$ & Low & 6 & 28.6 & 3 & 12.5 & 13 & 15.7 & 22 & 17.2 \\
\hline $0.40-0.60$ & Mean & 10 & 47.6 & 16 & 66.7 & 48 & 57.8 & 74 & 57.8 \\
\hline $0.60-0.80$ & High & 5 & 23.8 & 5 & 20.8 & 22 & 26.5 & 32 & 25.0 \\
\hline $0.80-1.00$ & Very high & - & - & - & - & - & - & - & - \\
\hline & $\overline{\mathbf{T A L}}$ & 21 & 100 & 24 & 100 & $\overline{83}$ & 100 & 128 & $\overline{100}$ \\
\hline
\end{tabular}

Evaluating forest fragments in an individualized way, it was possible to make findings about the environmental quality of these remaining areas. However, in order to facilitate the identification of fragments with higher or lower environmental quality, and therefore those that should be a priority for management and recovery actions, the information extracted from the aforementioned indicators was combined in a single index. The of index was then calculated and normalized to values between 0 and 1, making it possible to classify the fragments according to their environmental quality. Table 7 shows that there was no fragment classified with very low and/or very high environmental Evaluating forest fragments in an individualized way, it was possible to make findings about the environmental quality of these remaining areas. However, in order to facilitate the identification of fragments with higher or lower environmental quality, and therefore those that should be a priority for management and recovery actions, the information extracted from the aforementioned indicators was combined in a single index. The Qf index was then calculated and normalized to values between 0 and 1 , making it possible to classify the fragments according to their environmental quality. Table 7 shows that there was no fragment classified with very low and/or very high environmental quality. Most of them (57.8\%) were classified with average quality, $25.0 \%$ high and $17.2 \%$ with low environmental quality.

It was also noted that when evaluated by sub-basins these indices are similar, although there was predominance of high quality fragments especially in the low-lying sub-basin, as can be seen in Fig. 5(b).

\section{CONCLUSIONS}

By the analysis of the Environmental Quality Index (Qf) it was verified that most of the fragments present environmental quality classified as average. Although there are fragments that present high environmental quality in all sub-basins, most fragments classified as such are located in the lower course, which indicates that this is an area with high potential for the implementation of recovery and management measures.

The analysis of the connectivity vs isolation of the fragments revealed that most of the fragments are not completely isolated, which may indicate potential for the implementation of management and management measures such as ecological corridors.

\section{ACKNOWLEDGEMENT}

To the Foundation for Research Support the State of São Paulo (FAPESP) for the financial support for the execution of the research. 


\section{REFERENCES}

[1] Calegari, L. et al., Análise da dinâmica de fragmentos florestais no município de Carandaí, MG, para fins de restauração florestal. Revista Árvore, 34(5), pp. 871-880, 2010.

[2] Etto, T.L. et al., Ecologia da paisagem de remanescentes florestais na bacia hidrográfica do Ribeirão das Pedras, Campinas, SP. Revista Árvore, 37(6), pp. 10631071, 2013.

[3] Sampaio, R.C.N., Efeito de borda em um fragmento de floresta estacional semidecidual no interior do Estado de São Paulo, 2011, 83 f. Dissertação (Mestrado em Ciência Florestal), Universidade Estadual Paulista, Faculdade de Ciências Agronômicas, 2011. Online. http://hdl.handle.net/11449/99769. Accessed on: 22 Feb. 2017.

[4] Bierregaard, R.O. et al., The biological dynamics of tropical rainforest fragments: A prospective comparison of fragments and continuous forest. BioScience, 42(11), pp. 859-866, 1992.

[5] Zaú, A.S., Fragmentação da Mata Atlântica: Aspectos teóricos. Floresta e Ambiente, 5(1), pp. 160-170, 1998.

[6] Fengler, F.H. et al., Environmental quality of forest fragments in Jundiaí-Mirim river basin between 1972 and 2013. Revista Brasileira de Engenharia Agrícola e Ambiental, 19(4), pp. 402-408, 2015.

[7] Herrmann, B.C., Rodrigues, E. \& Lima, A., A paisagem como condicionadora de bordas de fragmentos florestais. Revista Floresta, 35(1), pp. 13-22, 2005.

[8] Bargos, D.C. \& Matias, L.F. Áreas verdes urbanas: Um estudo de revisão e proposta conceitual. Revista da Sociedade Brasileira de Arborização Urbana. Piracicaba, 6(3), pp. 172-188, 2011.

[9] Pirovani, D.B. et al., Análise espacial de fragmentos florestais na Bacia do Rio Itapemirim, ES. Revista Árvore, 38(2), pp. 271-281, 2014.

[10] Silva, K.G. et al., Análise da dinâmica espaço-temporal dos fragmentos florestais da sub-bacia hidrográfica do Rio Alegre, ES. CERNE, 21(2), pp. 311-318, 2015.

[11] Valente, R.O.A., Definição de áreas prioritárias para conservação e preservação florestal por meio da abordagem multicriterial em ambiente SIG, 2005. $121 \mathrm{f}$. Tese (Doutorado em Recursos Florestais), Universidade de São Paulo, Piracicaba, Online. www.teses.usp.br/teses/disponiveis/11/11150/tde-15062005-154402/pt-br.php.

Accessed on: 23 Feb. 2017.

[12] Silva, M.S.F. \& Melo, R., Padrões espaciais de fragmentação florestal na FLONA do Ibura, Sergipe. Revista Mercator, 13(3), pp. 121-137, 2014.

[13] Neto, R.S. et al., Caracterização da Cobertura Florestal de Unidades de Conservação da Mata Atlântica. Floresta e Ambiente, 22(1), pp. 32-41, 2015.

[14] Ranta, P. et al., The fragmented Atlantic rain forest of Brazil: Size, shape and distribution of forest fragments. Biodiversity and Conservation, 7, pp. 84-403, 1998.

[15] Silva, A.L. \& Longo, R.M., Influence of urbanization on the original vegetation cover in urban river basin: Case study in Campinas, SP, Brazil, EGU2017-5368. Geophysical Research Abstracts, 19, 2017, Online. http://meetingorganizer.copernicus.org/ EGU2017/EGU2017-5368.pdf. Accessed on: 15 Jun. 2017.

[16] Longo, R.M., Zangirolami, G.F., Yamaguchi, C.S., Demamboro, A.C., Bettine, S.C. \& Ribeiro, A.I., Impacts of agricultural activities in remaining forest: Campinas/SP, Brazil. WIT Transactions on Ecology and the Environment, vol. 170, WIT Press: Southampton and Boston, p. 15, 2013. 
[17] Longo, R.M. et al., Indicators of soil degradation in urban forests: physical and chemical parameters. WIT Transactions on Ecology and the Environment, vol. 162, WIT Press: Southampton and Boston, pp. 497-506, 2012.

[18] Gomes, R.C. et al., Water quality index in an urban watershed. International Journal of Sustainable Development and Planning: Encouraging the Unified Approach to Achieve Sustainability, 11, pp. 1037-1043, 2016.

[19] Freitas, E.P. et al., Indicadores ambientais para áreas de preservação permanente. Revista Brasileira de Engenharia Agrícola e Ambiental, 17(4), pp. 443-449, 2013.

[20] Chaves, H.M.L. \& Santos, L.B., Ocupação do solo, fragmentação da paisagem e qualidade da água em uma pequena bacia hidrográfica. Revista Brasileira de Engenharia Agrícola e Ambiental, 13, pp. 922-930, 2009.

[21] EMBRAPA - Empresa Brasileira De Pesquisa Agropecuárua, Aspectos Ecológicos, Online. www.cnpf.embrapa.br/pesquisa/efb/aspec.htm. Accessed on: 28 May 2017.

[22] IBGE - Instituro Brasileiro De Geografia E Estatística, Mapa de Clima do Brasil, Online. ftp://geoftp.ibge.gov.br/informacoes_ambientais/climatologia/mapas/brasil/ clima.pdf. Accessed on: 26 May 2017.

[23] Sistema ambiental paulista, Datageo. Infraestrutura de Dados Espaciais Ambientais do Estado de São Paulo - IDEA-SP. Base Territorial Ambiental Unificada, Online. http://datageo.ambiente.sp.gov.br/web/guest/inicio. Accessed on: 20 Feb. 2017.

[24] Nascimento, H.E.M. \& Laurance, W.F., Efeitos de área e de borda sobre a estrutura florestal em fragmentos de floresta de terra-firme após 13-17 anos de isolamento. Acta Amazônica, 36(2), pp. 183-192, 2006.

[25] Freitas, E.P., Análise integrada do mapa de uso e ocupação das terras da microbacia do Rio Jundiaí-Mirim para fins de gestão ambiental, 132 f. Dissertação (Mestrado em Agricultura Tropical e Subtropical), Instituto Agronômico de Campinas, Campinas, SP, 2012.

[26] Fengler, F.H., Qualidade ambiental dos fragmentos florestais na Bacia Hidrográfica do Rio Jundiaí-Mirim, 127 f. Dissertação (Mestrado em Agricultura Tropical e Subtropical), Instituto Agronômico de Campinas, Campinas, SP, 2014.

[27] Borges, L.F.R. et al., Inventário de fragmentos florestais nativos e propostas para seu manejo e o da paisagem. CERNE, 10(1), pp. 22-38, 2004.

[28] Carpi, S., Dagnino, R.S. \& Scaleante, O.A.F., Percepção e Mapeamento de Riscos em Campinas/SP. Olam Ciência \& Tecnologia, 7(1), pp. 545-568, 2007.

[29] Dário, F.R., Influência de corredor florestal entre fragmentos da mata atlântica utilizando-se a avifauna como indicador ecológico, 156 pp. Dissertação (Mestrado em Ciências), Universidade de São Paulo, Piracicaba, 1999.

[30] Moretti, A.I.P., Mapeamento de corredores ecológicos na APA Fernão Dias - MG a partir de técnicas de geoprocessamento e análise espacial, $154 \mathrm{f}$. Dissertação (Mestrado em Geografia), Universidade Estadual de Campinas, Instituto de Geociências, Campinas, 2005. 